\title{
Chromosome races with Pliocene origins: evidence from mtDNA
}

\author{
MARY MORGAN-RICHARDS*, STEVEN A. TREWICK \& GRAHAM P. WALLIS \\ Department of Zoology, University of Otago, PO Box 56, Dunedin, New Zealand
}

\begin{abstract}
There are eight distinct chromosomal races of the New Zealand weta Hemideina thoracica. We used mtDNA sequence data to test the hypothesis that these races originated on islands during the early Pliocene (7-4 million years ago). Nine major mitochondrial lineages were identified from 65 cytochrome oxidase I sequences. Phylogenetic analysis of these lineages suggests that they arose at approximately the same time. The geographical distribution of some lineages coincides with areas that were islands during the Pliocene. Overall, hierarchical AMOva analysis shows that chromosomal races and Pliocene islands describe only $28 \%$ and $24 \%$, respectively, of the total current mtDNA variation. However, removing one widespread (A) and one putatively introgressed (F) lineage increases these estimates to $65 \%$ and $80 \%$, respectively. Intraspecific sequence divergence was very high, reaching a maximum of $9.5 \%$ (uncorrected distance) and GC content was high compared to other insect mtDNA sequences. Average corrected distance among mtDNA lineages supports the Pliocene origins of this level of genetic diversity. In the southern part of the species range there is reduced mtDNA variation, probably related to local extinction of $H$. thoracica populations from recent volcanic activity and subsequent re-colonization from a leading edge. In contrast, in this southern part there are five chromosome races, suggesting that chromosome races here may be younger than those in the north.
\end{abstract}

Keywords: chromosome evolution, insect, mtDNA, New Zealand, phylogeography, Pliocene islands.

\section{Introduction}

Although many animal groups are karyotypically rather conserved, others, in particular small mammals (Searle, 1993) and orthopterans (White, 1978), are renowned for high intraspecific karyotypic diversity. Members of these groups often exist as geographically contiguous chromosome races bounded by sharp hybrid zones or stepped clines (Searle, 1993). The distributions of these races pose historical biogeographic questions about their origins, and their regions of narrow sympatry provide natural laboratories for analysis of gene flow between genetically differentiated forms (Barton \& Hewitt, 1985; Kocher \& Sage, 1986; Hewitt, 1988). Given a number of chromosome races with several contact zones, one can examine the level of gene flow in relation to the nature and extent of karyotypic differentiation. One of the potential confounding factors in this approach is that races and zones could be of quite different ages, and any reinforcement (Howard, 1993) or

*Correspondence and present address: Department of Botany, The Natural History Museum, Cromwell Road, London SW7 5BD, U.K. E-mail: marym@nhm.ac.uk reproductive character displacement (Butlin, 1989) of barriers to gene flow, or indeed their weakening through assimilation and selection, could disparately alter the levels of gene flow across zones. In this paper we aim to determine the origins of numerous chromosome races in an orthopteran (the weta, Hemideina thoracica) and determine whether they have approximately contemporaneous vicariant origins (Mayr \& O'Hara, 1986).

Weta are nocturnal flightless Orthoptera of the family Anostostomatidae (Johns, 1997). Endemic to New Zealand is a genus of arboreal, herbivorous weta (Hemideina) whose species are common and well studied. These species are sexually dimorphic; adult males use elongated mandibles in male-male combat for possession of tree cavities in which many adult females shelter during the day (Moller, 1985; Gwynne \& Jamieson, 1998). The Auckland weta $H$. thoracica White is found throughout much of the North Island of New Zealand, a range of approximately $1800 \mathrm{~km}^{2}$. Within this range eight karyotypically distinct 'races' are known (Morgan-Richards, 1997). A study of nuclear markers among populations of $H$. thoracica found little evidence of genetic differentiation, suggesting that chromosome races may have arisen quite recently. Mitochondria provide rapidly evolving 
haploid maternally inherited markers with a smaller effective population size, giving the ability to detect recent barriers to gene flow where nuclear markers fail (Avise, 1992). Thus a survey of mitochondrial markers has the potential to reveal genetic differentiation and provide an historical biogeographic framework to the analysis of gene flow through contact zones.

Greater diversity of both allozyme and chromosome markers was found in the northern part of the range of $H$. thoracica and led to the suggestion that a chain of early Pliocene (7-4 million years (Ma) ago) islands in the north of New Zealand may have facilitated the fixation of chromosome rearrangements (Fleming, 1979; Morgan-Richards, 1997). The Pliocene archipelago has since been connected by sand, volcanic activity and sea level changes. Some areas that were probably islands during the Pliocene have weta with unique karyotypes (North Cape, Karikari Peninsula). However, some weta populations on younger islands that were recently connected to the mainland ( $\sim 20000$ years ago), also have unique karyotypes (Cuvier Island, Double Island). If isolation on islands during the Pliocene did result in the formation of genetically distinct populations within this species then we predict that: (1) Areas that are considered to have been islands during the Pliocene would have distinct mitochondrial lineages. (2) Mitochondrial diversity would have arisen at approximately the same time due to divergence during a period of geographical isolation resulting in a number of lineages of approximately equal divergence. (3) The sequence divergence among mitochondrial lineages would match estimates based on the molecular-clock hypothesis. Both recent (Pleistocene) and older (Pliocene) isolation events may have facilitated fixation of novel chromosome rearrangements, and thus the possibility that the chromosomal races are of varying age will be considered.

\section{Materials and methods}

\section{Weta}

Weta were collected from the entire range of the species (Fig. 1). Some individuals were part of an earlier study that described the chromosome variation within this species. In this current study there are 32 new locations and 191 weta in total (Table 1). All weta collected were cytogenetically examined as described in MorganRichards (1997).

\section{$m t D N A$}

DNA was extracted from frozen muscle using a saltingout method (Sunnucks \& Hale, 1996). To avoid sequencing every individual, single stranded conformational polymorphism (SSCP) was used to identify haplotype variants (Sunnucks et al., 2000). Because mtDNA is inherited as a single non-recombining unit it was possible to use different regions of the genome for sorting and sequencing haplotypes. Universal insect mitochondrial primers SR-J-14233 and SR-N-14588 (Simon et al., 1994) were used to amplify a 355 base pair (bp) fragment of the small ribosomal subunit (12S) gene for SSCP screening. The $3^{\prime}$ end of cytochrome oxidase I (COI), which has been shown to be appropriate for intraspecific studies (Lunt et al., 1996; Trewick et al., 2000), was used for the majority of the sequence analysis. We expected to detect less variation in $12 \mathrm{~S}$ compared to that within $\mathrm{COI}$ due to the smaller size of the $12 \mathrm{~S}$ fragment used and its slower rate of evolution compared to COI (Simon et al., 1994). By selecting individuals to sequence based on the SSCP data we were maximizing the diversity detected within our sample and minimizing the number of identical or very similar haplotypes that we sequenced. The SSCP method followed Trewick (2000). A representative of each 12S-haplotype (as detected by SSCP) was then sequenced for a 550-bp fragment of the $C O I$ gene. Universal insect mitochondrial primers C1-J-2195 and L2-N-3014 (Simon et al., 1994) were used to amplify an 800-bp fragment. PCR products were gel-purified and cleaned using Qiaquick spin columns. DNA was sequenced using Bigdye chemistry (Perkin Elmer) following the manufacturer's protocols using primer C1-J-2195, to give a 550-bp fragment of the $3^{\prime}$ end. Sequences were aligned by eye using SeqEd. v1.0.3 (ABI, PE).

\section{Phylogenetic analysis}

PAUP*4.0b (Swofford, 1998) was used to implement various methods of phylogenetic reconstruction: Maximum Likelihood (ML), Maximum Parsimony (MP) and Neighbour Joining (NJ). Tests for homogeneity and clock-like evolution of the sequences using a likelihood difference test (Felsenstein, 1988) were also performed in PAUP*. Transversion/transition ratio and number of invariant sites were calculated using MacClade 3.07 (Maddison \& Maddison, 1992) and a NJ tree.

\section{Population genetics}

The AMova method of Excoffier et al. (1992) was implemented by ARLEQUIN 1.0 (Schneider et al., 1997). The SSCP 12S-haplotype frequency data was used with a distance matrix based on $C O I$ sequences. Hierarchical analysis was performed across chromosomal races and 
Fig. 1 Collecting locations for Hemideina thoracica from North Island, New Zealand. Unlabelled spots indicate locations where weta have only been cytogenetically examined. Shaded areas indicates land above $150 \mathrm{~m}$. Inset shows the hypothesized distribution of land during the early Pliocene and the shoreline during glacial maxima (Fleming, 1979; Stevens, 1981; Ballance \& William, 1992).

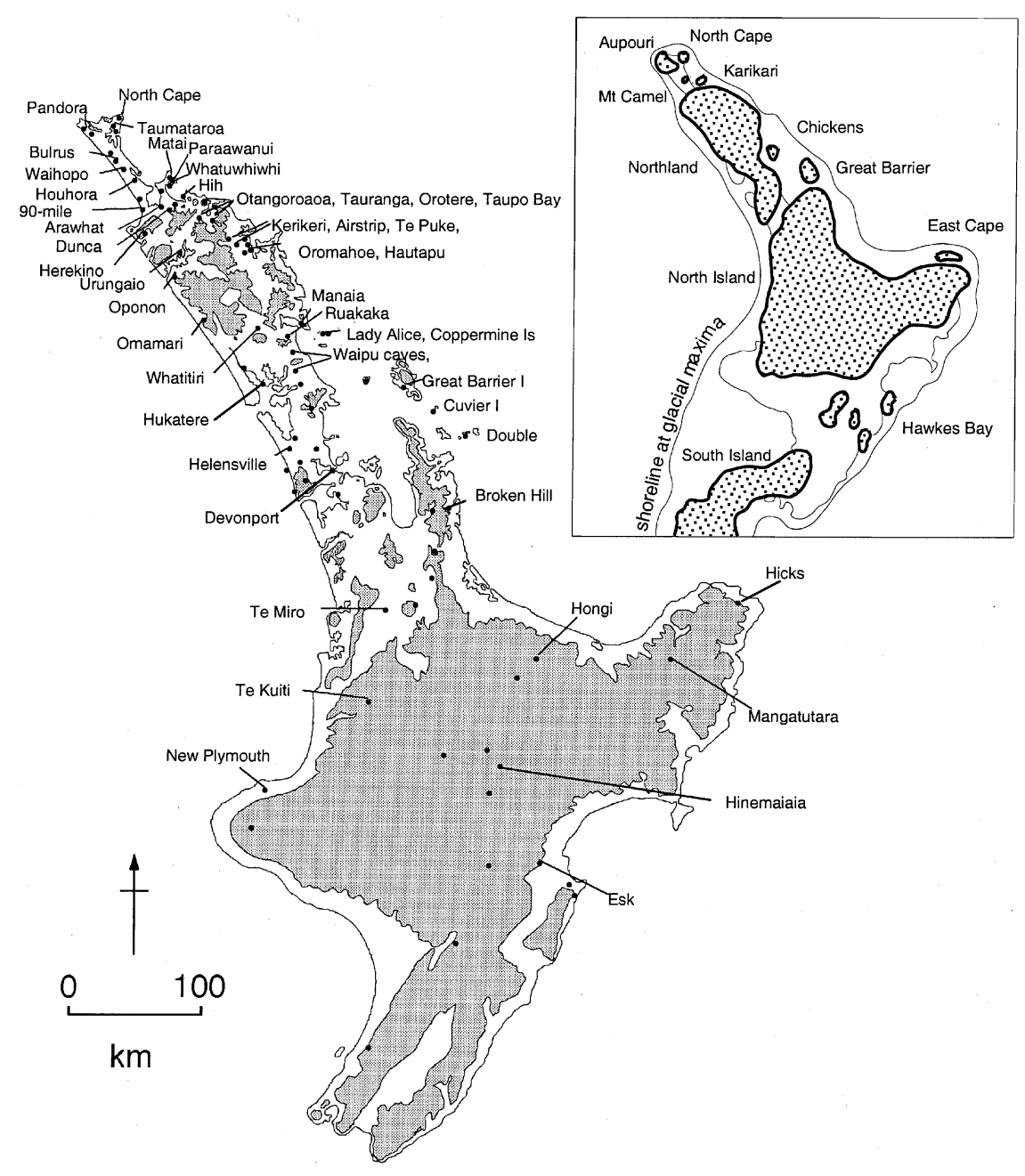

across Pliocene Islands based on geological evidence (Fig. 1; Fleming, 1979; Stevens, 1981; Ballance \& Williams, 1992).

Isolation by distance was tested using geographical distances between locations and pairwise K2P genetic distances. One representative of each haplotype from each location was used. Sample sizes range from 1 to 14 weta per location while numbers of haplotypes per location range from 1 to 4 . A Mantel test was implemented in GENEPOP (Raymond \& Rousset, 1995) using 1000 iterations.

\section{Results}

The known geographical distribution of the eight chromosomal races of $H$. thoracica has been extended and refined (Table 1, Fig. 2). The 13-karyotype previously known only from Double Island, has now been recorded at four sites adjacent to each other on North Island, $120 \mathrm{~km}$ west of Double Island.
This is only the second instance of a chromosome race within $H$. thoracica having a disjunct distribution. The known range of the 19-karyotype race has been extended west, the range of $17^{\prime}$-karyotype extended south and the $15^{\prime}$-karyotype range extended north.

Fifty-eight unique 12S-SSCP haplotypes were identified. Fifteen of 31 locations from which more than one weta were studied showed only a single haplotype (Table 1). The maximum number of haplotypes in any sample was four (Orotere, $n=5$ ). A representative of each 12S-SSCP haplotype was sequenced for COI. Additionally, five 12S-SSCP haplotypes were sequenced in duplicate and one haplotype in triplicate, so sequence information was obtained for 65 weta. In five cases, the same 12S-SSCP haplotypes gave an identical COI sequence, and two other COI sequence comparisons differed by $1 \mathrm{bp}$ and $2 \mathrm{bp}$.

COI sequences showed 159 variant nucleotide sites in the $550 \mathrm{bp}$ observed. Nucleotide composition was

(C) The Genetics Society of Great Britain, Heredity, 86, 303-312. 
Table 1 Collecting locations for Hemideina thoracica from North Island, New Zealand, showing sample sizes, number of SSCP-haplotypes, mtDNA lineage, karyotype and Pliocene land mass closest to the location

\begin{tabular}{|c|c|c|c|c|c|c|c|c|}
\hline Location & $\begin{array}{l}\text { South } \\
\text { latitude }\end{array}$ & $\begin{array}{c}\text { East } \\
\text { longitude }\end{array}$ & $\begin{array}{l}\text { No. of } \\
\text { weta } \\
\text { (SSCP) }\end{array}$ & $\begin{array}{l}\text { No. } \\
\text { haplo } \\
(C O I)\end{array}$ & $\begin{array}{l}\text { No. of } \\
\text { sequences }\end{array}$ & $\begin{array}{l}\text { mtDNA } \\
\text { lineage }\end{array}$ & Karyotype & $\begin{array}{l}\text { Closest } \\
\text { Pliocene } \\
\text { Island }\end{array}$ \\
\hline Esk & 3921 & 17642 & 2 & 1 & 1 & A & 17 & North \\
\hline Hinemaiaia & 3851 & 17601 & 14 & 1 & 1 & A & 17 & North \\
\hline Hongi & 3844 & 17610 & 1 & 1 & 1 & A & 15 & North \\
\hline Te Kuiti & 3821 & 17510 & 1 & 1 & 1 & A & 15 & North \\
\hline Mangatutara & 3755 & 17451 & 1 & $1^{*}$ & 1 & A & 17 & North \\
\hline Te Miro & 3749 & 17533 & 1 & $1^{*}$ & 1 & A & 15 & North \\
\hline Broken Hill & 3707 & 17543 & 1 & 1 & 1 & A & 17 & North \\
\hline Devonport & 3649 & 17450 & 1 & 1 & 1 & A & $15^{\prime}$ & Northland \\
\hline Helensville & 3642 & 17429 & 1 & 1 & 1 & A & 13 & Northland \\
\hline Cuvier I & 3626 & 17546 & 1 & 1 & 1 & A & 11 & North \\
\hline Hukatere & 3611 & 17410 & 1 & 1 & 1 & A & $15^{\prime}$ & Northland \\
\hline Ahuroa & 3559 & 17425 & 12 & $3^{*}$ & 3 & A & $15^{\prime}$ & Northland \\
\hline Waipu caves & 3556 & 17422 & 8 & $2^{*}$ & 1 & A & $15^{\prime}$ & Northland \\
\hline Ruakaka & 3552 & 17424 & 6 & $2^{*}$ & 1 & A & 17 & Northland \\
\hline Manaia & 3549 & 17430 & 1 & $1^{*}$ & 1 & A & 17 & Northland \\
\hline Omamari & 3549 & 17344 & 1 & 1 & 1 & A & $15^{\prime}$ & Northland \\
\hline Whatitiri & 3547 & 17409 & 3 & 1 & 1 & A & 17 & Northland \\
\hline Hautapu & 3523 & 17400 & 4 & $2 *$ & 1 & A & 17 & Northland \\
\hline Oromahoe & 3519 & 17407 & 4 & $1^{*}$ & 1 & A & 17 & Northland \\
\hline Paihia & 3518 & 17405 & 4 & $1^{*}$ & 1 & A & 17 & Northland \\
\hline Airstrip & 3516 & 17355 & 4 & $3^{*}$ & 2 & A & 19 & Northland \\
\hline Te Puke & 3515 & 17402 & 10 & 1 & 1 & A & 19 & Northland \\
\hline Kerikeri & 3513 & 17358 & 1 & 1 & 1 & A & 19 & Northland \\
\hline New Plymouth & 3904 & 17404 & 6 & 1 & 1 & B & 15 & North \\
\hline Double I & 3637 & 17553 & 1 & 1 & 1 & $\mathrm{C}$ & 13 & North \\
\hline Hicks & 3735 & 17827 & 1 & 1 & 1 & $\mathrm{C}$ & 15 & East Cape \\
\hline Lady Alice I & 3554 & 17443 & 1 & 1 & 1 & $\mathrm{D}$ & $15^{\prime}$ & Chickens \\
\hline Coopermine I & 3554 & 17446 & 1 & 1 & 1 & $\mathrm{D}$ & $15^{\prime}$ & Chickens \\
\hline Great Barrier I & 3618 & 17530 & 1 & 1 & 1 & D & 17 & Great Barrier \\
\hline Orotere & 3507 & 17352 & 5 & $4^{*}$ & 4 & $\mathrm{E}$ & 19 & Northland \\
\hline Otangoroaoa & 3504 & 17340 & 2 & $2^{*}$ & 1 & E & 19 & Northland \\
\hline Tauranga & 3500 & 17347 & 6 & $3^{*}$ & 3 & E & 19 & Northland \\
\hline Taupo Bay & 3459 & 17342 & 8 & $2^{*}$ & 1 & E & 19 & Northland \\
\hline Waihopo & 3446 & 17304 & 3 & 1 & 1 & $\mathrm{~F}$ & $17^{\prime}$ & Mt Camel \\
\hline Hauhora & 3450 & 17309 & 3 & 1 & 1 & $\mathrm{~F}$ & $17^{\prime}$ & Mt Camel \\
\hline 90-mile & 3501 & 17315 & 6 & 1 & 1 & $\mathrm{~F}$ & 19 & Northland \\
\hline Herekino & 3510 & 17316 & 3 & $1^{*}$ & 1 & $\mathrm{~F}$ & 19 & Northland \\
\hline Arawhata & 3502 & 17319 & 2 & 1 & 1 & $\mathrm{~F}$ & 19 & Northland \\
\hline Duncan & 3503 & 17321 & 12 & 3 & 3 & $\mathrm{~F}$ & 19 & Northland \\
\hline Urungaio & 3618 & 17331 & 2 & $2^{*}$ & 1 & $\mathrm{~F}$ & 19 & Northland \\
\hline Opononi & 3531 & 17324 & 1 & 1 & 1 & $\mathrm{~F}$ & 19 & Northland \\
\hline Hihi & 3458 & 17332 & 9 & 1 & 1 & $\mathrm{~F}$ & 19 & Northland \\
\hline Whatuwhiwhi & 3453 & 17324 & 12 & $1^{*}$ & 2 & $\mathrm{~F}$ & 23 & Karikari \\
\hline Matai & 3451 & 17325 & 4 & $1^{*}$ & 2 & $\mathrm{G}$ & 23 & Karikari \\
\hline Paraawanui & 3450 & 17326 & 2 & $2^{*}$ & 2 & G \& F & 23 & Karikari \\
\hline Bulrush & 3443 & 17301 & 4 & 2 & 2 & H \& F & $17^{\prime}$ & Mt Camel \\
\hline Pandora & 3429 & 17246 & 8 & 2 & 2 & I & $17^{\prime}$ & Aupouri \\
\hline North Cape & 3425 & 17302 & 2 & $2 *$ & 2 & I & $17^{\prime}$ & North Cape \\
\hline Taumataroa & 3427 & 17258 & 4 & $2^{*}$ & 1 & I & $17^{\prime}$ & North Cape \\
\hline 49 & & & 192 & 58 & 65 & & & \\
\hline
\end{tabular}

* Some haplotypes observed at adjacent sites. 


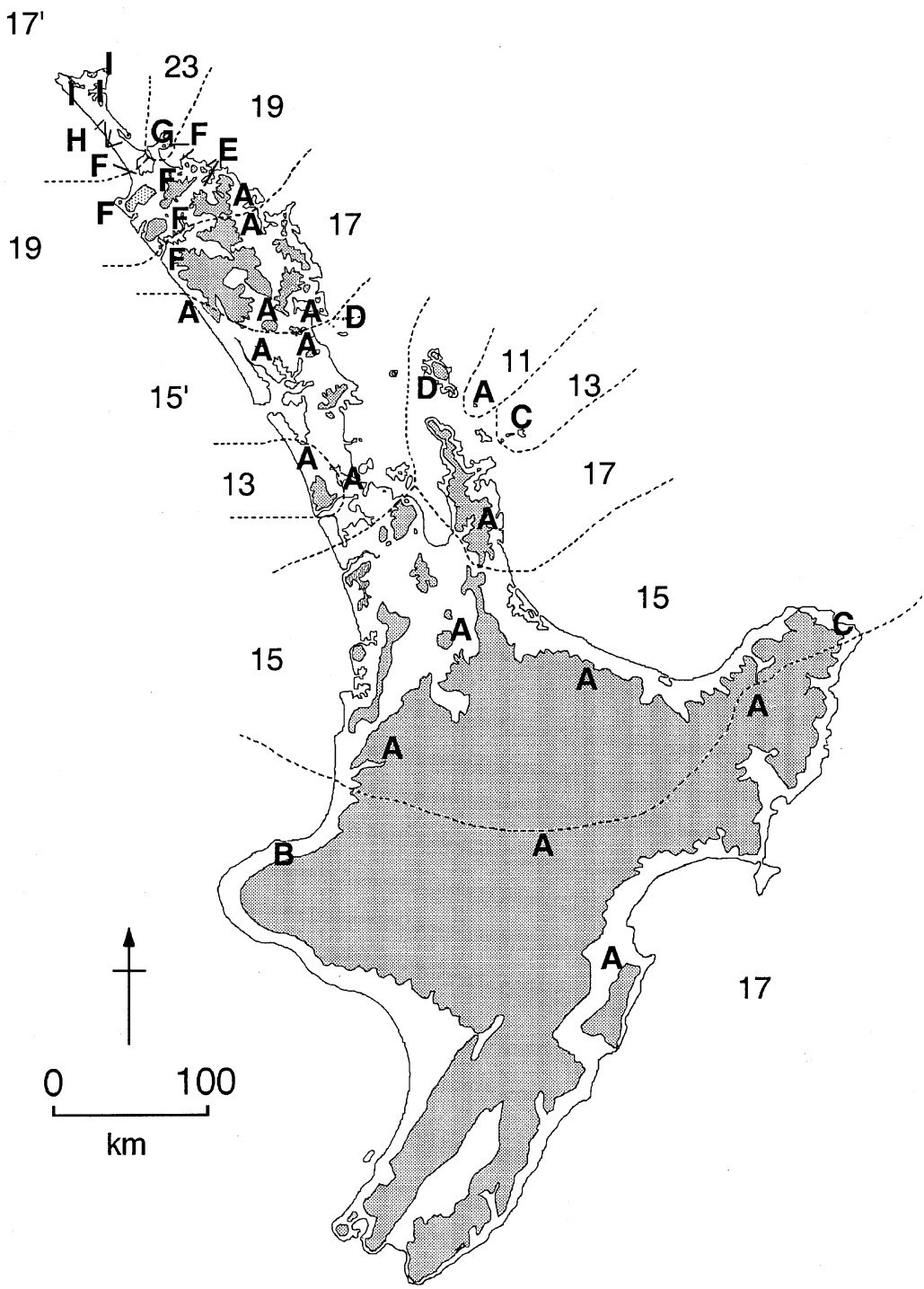

Fig. 2 The distribution of eight chromosome races (11-23; dotted lines) and nine mitochondrial lineages $(\mathrm{A}-\mathrm{I})$ of Hemideina thoracica in North Island, New Zealand.

marginally AT biased (A $+\mathrm{T}=58 \%$ ), lower than most values for insect mtDNA and more typical of a vertebrate (Frati et al., 1997; Langor \& Sperling, 1997; Saccone et al., 1999; Trewick, 2000). A transition: transversion ratio of $4.2: 1$ was obtained using the NJ tree.

\section{Genetic distances}

An appropriate nucleotide substitution model for estimating genetic distances was calculated using the 65 COI sequences. An initial NJ tree based on K2P was used as a starting point for Maximum Likelihood analysis and the likelihood scores for a suite of models were compared: JC (Jukes \& Cantor, 1969), K2P (Kimura, 1980), HKY85 (Hasegawa et al., 1985) and GTR (Yang, 1994), with a combination of among-site rate variation models: I (invariable sites) and $\Gamma$ (gamma distribution) using four rate categories (increasing the rate categories to 8 did not affect which model performed best). HKY $+\mathrm{I}+\Gamma$ was the simplest model that was not significantly worse than any of the more parameter-rich models, therefore this model was used to calculate the pairwise genetic distances and used in NJ analyses. The maximum uncorrected distance (p) between any two sequences was 9.5\%. With HKY $+\mathrm{I}+\Gamma$ correction the maximum pairwise distance was $16.3 \%$ (data available from authors on request).

\section{Phylogenetics}

$\mathrm{NJ}$ with $65 \mathrm{COI}$ sequences resolved nine major lineages (A-I, Fig. 3). These lineages were obtained with a fastbootstrap MP search (2000 iterations). At only two locations (Paraawanui and Bulrush) was more than one 


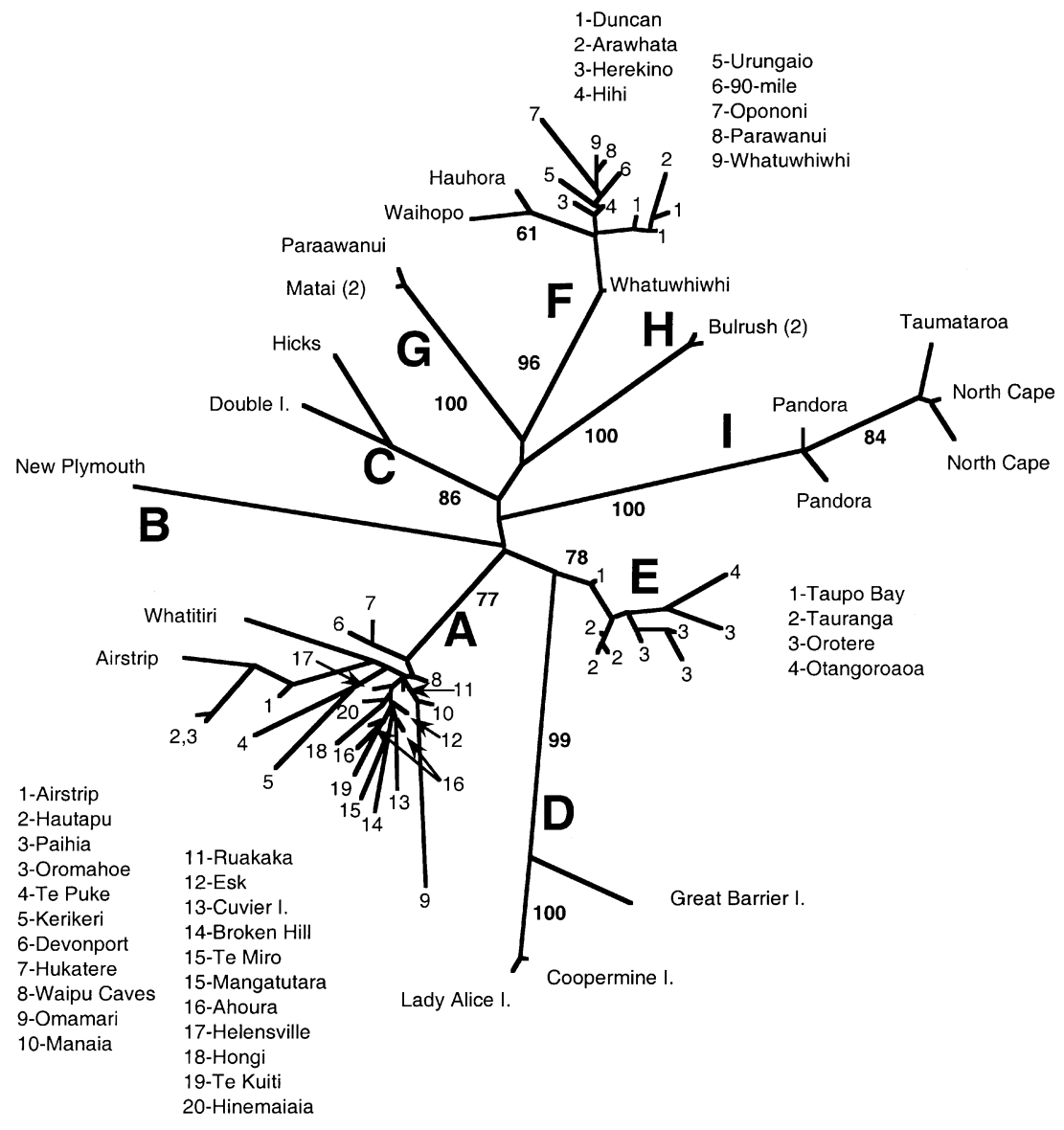

Fig. 3 Neighbour-Joining tree of $\mathrm{HKY}+\mathrm{I}+\Gamma$ distances of $\mathrm{COI}$ from 65 Hemideina thoracica. Principal lineages are coded with a letter (A-I). Numbers on branches show percentage support from 2000 bootstrap replicates using MP and 4:1 tv:ts weighting.

Table 2 Average pairwise genetic distances $(\mathrm{HKY}+\mathrm{I}+\Gamma)$ within and among the nine major mtDNA lineages in Hemideina thoracica

\begin{tabular}{lccccccccc}
\hline & $\mathrm{A}$ & $\mathrm{B}$ & $\mathrm{C}$ & $\mathrm{D}$ & $\mathrm{E}$ & $\mathrm{F}$ & $\mathrm{G}$ & $\mathrm{H}$ & $\mathrm{I}$ \\
\hline $\mathrm{A}$ & 0.030 & & & & & & & & \\
$\mathrm{~B}$ & 0.096 & & & & & & & & \\
$\mathrm{C}$ & 0.082 & 0.090 & 0.030 & & & & & \\
$\mathrm{D}$ & 0.106 & 0.112 & 0.110 & 0.022 & & & & \\
$\mathrm{E}$ & 0.066 & 0.096 & 0.057 & 0.072 & 0.013 & & & \\
$\mathrm{~F}$ & 0.105 & 0.085 & 0.088 & 0.101 & 0.089 & 0.017 & & \\
$\mathrm{G}$ & 0.086 & 0.975 & 0.081 & 0.104 & 0.075 & 0.069 & 0.001 & 0.000 & 0.022 \\
$\mathrm{H}$ & 0.084 & 0.976 & 0.062 & 0.098 & 0.061 & 0.073 & 0.062 & 0.102 & 0.025 \\
$\mathrm{I}$ & 0.106 & 0.134 & 0.095 & 0.139 & 0.099 & 0.125 & 0.119 & & \\
\hline
\end{tabular}

major lineage observed. Average genetic distances $(\mathrm{HKY}+\mathrm{I}+\Gamma)$ among the nine major lineages were all above $5 \%$ (Table 2).

Due to the computational time required for a data set of this size, a subset of sequences was chosen for further analysis. One member of each major mtDNA lineage (A-I) was randomly selected, plus an additional sequence for lineage A, C, D, F and I. For these 14 weta the $12 \mathrm{~S}$ fragment previously used for SSCP was sequenced.
A partition homogeneity test $(P=0.140)$ was performed before combining $C O I$ and $12 \mathrm{~S}$ data. One hundred and five nucleotide sites were variable over these $840 \mathrm{bp}$. MP (weighting: tv:ts 4:1) gave a single tree with each major lineage well supported ( $>80 \%$ bootstrap support), but the highest inter-lineage bootstrap value was only $56 \%$ for $\mathrm{A}+\mathrm{B}$.

To test whether the sequences had evolved in a clocklike fashion we used the subset of 14 taxa. We 
constrained the most likely tree found under ML to conform to a molecular clock and found using a $\chi^{2}$ test that this did not differ significantly in likelihood scores. Neither the combined data set (COI and 12S) nor COI analysed separately differed significantly from a clocklike model.

\section{Population genetics}

The majority of sites from which weta were collected had unique mtDNA haplotypes (Table 1). In 20 samples, haplotypes were shared by adjacent sites. Distances between these sites ranged from 2 to $212 \mathrm{~km}$. The nine major mtDNA lineages showed some geographical structure, with adjacent locations generally sharing the same lineage (Fig. 2). The range of the nine mtDNA lineages varied considerably, with six lineages (B, C, D, $\mathrm{G}, \mathrm{H}$ and $\mathrm{I}$ ) detected at three or fewer locations. Lineage $\mathrm{A}$ was found at 23 locations and $\mathrm{F}$ at 12 . The most widespread lineage (A) was found throughout much of the southern $3 / 4$ of the species' range, and the greatest distance between any two locations having A was $525 \mathrm{~km}$. No evidence of isolation by distance was found using all haplotypes (Mantel test, $P=0.912$ ). The distribution of genetic variation was analysed with hierarchical $\Phi$-statistics using AMOva (Excoffier et al., $1992) ; \Phi_{\mathrm{SC}}$ quantifies the proportion of genetic variation within groups (chromosome races or Pliocene islands), $\Phi_{\mathrm{ST}}$ is the variation among all populations and $\Phi_{\mathrm{CT}}$ is the variation among groups. Two groupings were explored. Populations were grouped according to their karyotypes and according to the hypothesized Pliocene island they were closest to. These levels of division described relatively little of the total genetic diversity within the species; the majority of genetic diversity being attributed to comparisons among samples within groups (with eight chromosome races $\Phi_{\mathrm{SC}}=0.94, \Phi_{\mathrm{ST}}=0.96$, $\Phi_{\mathrm{CT}}=0.28$; with nine Pliocene islands $\Phi_{\mathrm{SC}}=0.94$, $\left.\Phi_{\mathrm{ST}}=0.96, \quad \Phi_{\mathrm{CT}}=0.24\right)$. Rather than rejecting the significance of the Pliocene islands and chromosome races as potential causal factors of the major lineages, we performed some exploratory data analyses, omitting two selected lineages that we felt to be atypical. The first, selected lineage was lineage $\mathrm{A}$, which is considerably more widespread that any other lineage, encompassing several Pliocene island regions and chromosomal races. This is in keeping with its southern distribution and the eradication of much of the biota of central North Island by repeated eruptions of Taupo, the largest 20000 years ago (see Discussion). The second selected lineage was $\mathrm{F}$; although lineage $\mathrm{F}$ is found only in Northland, it does occur peripherally on adjacent Mt Camel and Karikari areas, and may well indicate more recent gene flow. When the hierarchical $\Phi$-statis-
Table 3 Hierarchical $\Phi$-statistics (Excoffier et al., 1992) for Hemideina thoracica

\begin{tabular}{lcccc}
\hline$\Phi_{\mathrm{CT}}$ & $\begin{array}{c}\text { All } \\
\text { lineages }\end{array}$ & $\begin{array}{c}\text { Without } \\
\text { A }\end{array}$ & $\begin{array}{c}\text { Without } \\
\mathrm{F}\end{array}$ & $\begin{array}{c}\text { Without } \\
\text { A \& F }\end{array}$ \\
\hline $\begin{array}{l}\text { Chromosome } \\
\text { races }\end{array}$ & 0.28 & 0.23 & 0.36 & 0.65 \\
$\begin{array}{l}\text { Pliocene } \\
\text { Islands }\end{array}$ & 0.24 & 0.37 & 0.37 & 0.81 \\
\hline $\begin{array}{l}\text { No. locations } \\
\text { No. weta }\end{array}$ & 49 & 26 & 39 & 16 \\
\hline
\end{tabular}

$\Phi_{\mathrm{CT}}$, genetic variation among races or islands.

tics analysis was repeated without one or other of these lineages, the picture did not change greatly, but with both removed the proportions of variation described increased to $65 \%$ for chromosomes and $81 \%$ for islands (Table 3).

\section{Discussion}

Paraawanui and Bulrush had weta with mtDNA haplotypes that differed by $5.8 \%$ and $7.6 \%$ (lineages $\mathrm{F}, \mathrm{G}$ and $\mathrm{F}, \mathrm{H})$. Although these distances are more typical of interspecific comparisons in insects (Funk, 1999), these weta had identical karyotypes and were morphologically indistinguishable. Four mtDNA lineages were found in more than one chromosomal race $(\mathrm{A}, \mathrm{C}, \mathrm{D}, \mathrm{F})$. Thus, the distribution of the mtDNA markers suggests that gene flow between chromosomal races is possible and supports the idea that $H$. thoracica is a single interbreeding species. The distribution of haplotypes and the level of divergence are indicative of a species that has extremely low dispersal. Gene flow is apparently low enough to allow differentiation of populations, as sampled at this scale, as almost every location has a novel haplotype.

\section{Pliocene islands with distinct mitochondrial lineages}

There is varying concordance between mtDNA lineages and Pliocene islands. For example, the distributions of lineages $\mathrm{G}, \mathrm{H}$, and I coincide exactly with islands in the far north. The rare presence of two deep lineages at a single location is strongly suggestive of recent gene flow. Range expansion of haplotypes is suggested by the distribution of lineage $F$ which is found on the boundaries of the 19-karyotype and has apparently crossed into the range of the 17'-, 23- and 17-karyotypes. Removal of this lineage from the AMOVA analysis increased the proportion of total 
genetic variation that was described by both the chromosomal races and the Pliocene island partitioning of the data. The distribution of lineages $\mathrm{A}, \mathrm{C}$ and $\mathrm{D}$ also implies dispersal over longer distances from Pliocene refugia. The occurrence of lineage $\mathrm{B}$ on the Mt Taranaki volcano cannot be explained by Pliocene islands or chromosome races as currently hypothesized.

\section{Lineages of equal divergence}

The topology of the phylogenetic hypothesis for the mtDNA of $H$. thoracica is star-like, with no resolution of the relationships among the major lineages. Although nine clades have bootstrap values of $78 \%$ or above (A-I) no edges connecting these lineages have good bootstrap support. Even with fewer taxa and a longer sequence $(840 \mathrm{bp})$ the relationships between major lineages remain unresolved. There are two possible explanations; either the data set is saturated at this level or these lineages began to diverge at approximately the same time. Other studies have resolved relationships using this region of $C O I$ and with similar levels of divergence (Langor \& Sperling, 1997). Similar studies of insect COI frequently find lower tv/ts ratios within species and at levels of divergence lower than we observed (Caterino \& Sperling, 1999). Our estimation of I (invariant sites) suggests that there are sites still free to vary and the fact that other studies have recorded divergences of $30 \%$ between insect COI sequences (Stauffer et al., 1997) also indicates that saturation is not a feature of our data.

\section{Molecular-clock hypothesis}

Both the combined sequences data set and a subset of COI sequences have apparently evolved in a clock-like fashion. For insect mtDNA, calibration has been based on geological events $<3.5 \mathrm{Ma}$ ago and have used a mixture of uncorrected and corrected sequence divergences (Brower, 1994; Knowlton \& Weigt, 1998). Although the levels of divergence observed in this study are somewhat higher, we have used evolutionary models in the correction of genetic distances that should compensate for the nonlinear relationship between time and observed rate. Rate estimations vary from 1.2 to 0.7\% per Ma (Brower, 1994; Knowlton \& Weigt, 1998). Average pairwise genetic distances $(\mathrm{HKY}+\mathrm{I}+\Gamma)$ between mtDNA lineages of $H$. thoracica range from $13.9 \%$ to $5.7 \%$. Using the range of rate estimates these values correspond to 5.8-9.9 and 2.4-4.1 Ma since the last common ancestor. The majority of estimates therefore place the divergence of these lineages in the early Pliocene.

\section{Chromosomal races of varying age}

In the extreme north of the range of $H$. thoracica, there is close correspondence of mtDNA lineages with chromosomal races and Pliocene islands. On the other hand, the widespread distribution of lineage A may be a result of more recent geological and climatic events. The central area of the North Island was greatly modified by volcanic eruptions. Approximately 20000 years ago the largest of the Taupo eruptions destroyed all land surfaces in central North Island (Ballance \& Williams, 1992) and more recent eruptions (2000 years ago) destroyed approximately $20000 \mathrm{~km}^{2}$ of forest in central North Island (Wilson \& Walker, 1985). As the forest re-established a large area would have been available for re-colonization by the southward dispersal of $H$. thoracica. The consequence of recent range expansion is likely to be loss of genetic diversity through leading-edge re-colonization (Wallis \& Arntzen, 1989; Phillips, 1994; Hewitt, 1999). In addition to volcanic activity, the fluctuations in climate during the Pleistocene may have caused range expansion and contraction of $H$. thoracica in lower North Island. There is good evidence that $H$. thoracica has recently expanded south and displaced a close relative, $H$. crassidens, from all but high altitude regions of central North Island (Trewick \& MorganRichards, 1995). The pattern of reduced mtDNA diversity in the southern half of the range of $H$. thoracica is paralleled by the allozyme data (Morgan-Richards, 1997), although karyotypic diversity is less affected. This disparity could be explained by recent origins of the chromosomal races that have the A mtDNA lineage $\left(11,13,15,15^{\prime}, 17\right)$ resulting from fixation during local extinction and re-colonization (Lande, 1979) or the retention of ancestral polymorphism. On the other hand, introgression of lineage $\mathrm{A}$ into the range of mtDNA lineages $\mathrm{C}$ and $\mathrm{D}$ (karyotypes 15, 15', 17 and 13) cannot be excluded.

In conclusion, $H$. thoracica is a single species with an unprecedented level of mtDNA divergence. Support for the idea that this divergence arose during periods of population isolation on islands that existed during the Pliocene comes from the level of divergence, the apparent simultaneous origins of the lineages and the match between current range of some of the mtDNA markers and hypothesized islands. However, due to the intraspecific nature of this variation, introgression of lineages into neighbouring populations has reduced the correspondence of mtDNA with islands and with chromosomal races. The age of some of the northern chromosomal rearrangements $\left(17^{\prime}, 23\right.$ and 19) may date from the same period of Pliocene isolation, but southern chromosomal races probably have a more recent origin. The age of the chromosomal races within this species is 
in contrast to many studies that have found evidence of extremely recent and rapid karyotype evolution. For example, in the shrew Sorex araneus mtDNA diversity suggests that chromosomal rearrangements have arisen within the last $1 \mathrm{Ma}$ (Taberlet et al., 1994). In the house mouse (Mus domesticus) five chromosome races may have arisen on Madeira in 500 years (Britton-Davidian et al., 2000), and in an aphid (Sitobion) the rate of chromosome evolution exceeds the rate of microsatellite evolution (Sunnucks et al., 1996). The antiquity of the chromosome races of $H$. thoracica is more remarkable given that these populations have apparently survived as distinct units and yet remained as part of a single species for millions of years, especially when one considers the climate changes during the Pleistocene, and the continuity of land during glacial maxima.

\section{Acknowledgements}

We thank George Gibbs, Lauren Turner, Michele Frank, Ray Pierce, Alan Summers and the Department of Conservation for help collecting weta and Jack Sullivan, Thomas Buckley and Martyn Kennedy for help with the data analysis. This work was supported by Marsden Grant PVT-601 administrated by the Royal Society of New Zealand.

\section{References}

AVISE, J. C. 1992. Molecular population structure and the biogeographic history of a regional fauna: a case history with lessons for conservation. Oikos, 63, 62-76.

BALlANCE, P. F. AND WILliams, P. W. 1992. The Geomorphology of Auckland and Northland. In: Soons, J. M. and Selby, M. J. (eds) Landforms of New Zealand, pp. 210-232. Longman Paul Ltd, Hong Kong.

BARTON, N. H. AND HEWITT, G. M. 1985. Analysis of hybrid zones. Ann. Rev. Ecol. Syst., 16, 113-148.

BRITTON-DAVIDIAN, J., CATALAN, J., RAMALHINHO, M. G., GANEM, G. ET AL. 2000. Rapid chromosomal evolution in island mice. Nature, 403, 158.

BROWER, A. V. Z. 1994. Rapid morphological radiation and convergence among races of the butterfly Heliconius erato inferred from patterns of mitochondrial DNA evolution. Proc. Natl. Acad. Sci. U.S.A., 91, 6491-6495.

BUTLIN, R. 1989. Reinforcement of premating isolation. In: Otte, D. and Endler, J. A. (eds) Speciation and Its Consequences, pp. 158-179. Sinauer, Sunderland, MA.

CATERINO, M. S. AND SPERLING, F. A. H. 1999. Papilio phylogeny based on mitochondrial cytochrome oxidase I and II genes. Mol. Phyl. Evol., 11, 122-137.

EXCOFfIER, L., SMOUSE, P. E. AND QuATtro, J. M. 1992. Analysis of molecular variance inferred from metric distance among DNA haplotypes: applications to human mitochondrial DNA restriction data. Genetics, 131, 479-491.
FELSENSTEIN, J. 1988. Phylogenies from molecular sequences: inference and reliability. Ann. Rev. Genet., 22, 521-565.

FLEMING, C. A. 1979. The Geological History of New Zealand and Its Life. Auckland University Press, Auckland.

FRATI, F., SIMON, C., SUllivAN, J. AND SWOFFORD, D. L. 1997. Evolution of the mitochondrial cytochrome oxidase II gene in Collembola. J. Mol. Evol., 44, 145-158.

FUNK, D. J. 1999. Molecular systematics of cytochrome oxidase I and $16 \mathrm{~S}$ from Neochlamisus leaf beetles and the importance of sampling. Mol. Biol. Evol., 16, 67-82.

GWYNNE, D. T. AND JAMIESON, I. 1998. Sexual selection and sexual dimorphism in a harem-polygynous insect, the alpine weta (Hemideina maori, Orthoptera Stenopelmatidae). Ethol. Ecol. Evol., 10, 393-402.

HASEgAWA, M., KISHINO, H. AND TANO, T. 1985. Dating the human-ape splitting by a molecular clock of mitochondrial DNA. J. Mol. Evol., 22, 160-174.

HEWITT, G. M. 1988. Hybrid zones - natural laboratories for evolutionary studies. Trends Ecol. Evol., 3, 158-167.

HEWITT, G. M. 1999. Post-glacial re-colonization of European biota. Biol. J. Linn. Soc., 68, 87-112.

HOWARD, D. J. 1993. Reinforcement: Origin, dynamics, and fate of an evolutionary hypothesis. In: Harrison, R. G. (ed.) Hybrid Zones and the Evolutionary Process, pp. 46-69. Oxford University Press, New York.

JohnS, P. M. 1997. The Gondwanaland weta: Family Anostostomatidae (formerly in Stenopelmatidae, Henicidae or Mimnermidae): Nomenclature problems, world checklist, new genera and species. J. Orthopt. Res., 6, 125-138.

JUKES, T. H. AND CANTOR, C. R. 1969. Evolution of protein molecules. In: Munro, H. N. (ed.) Mammalian Protein Metabolism, pp. 21-132. Academic Press, New York.

KIMURA, M. 1980. A simple method for estimating evolutionary rate of base substitutions through comparative studies of nucleotide sequences. J. Mol. Evol., 16, 111-120.

KNOWLTON, N. AND WEIGT, L. A. 1998. New dates and new rates for divergence across the Isthmus of Panama. Proc. R. Soc. $B, \mathbf{2 6 5}, 2257-22683$.

KOCHER, T. D. AND SAGE, R. D. 1986. Further genetic analyses of a hybrid zone between leopard frogs (Rana pipiens complex) in Central Texas. Evolution, 40, 21-33.

LANDE, R. 1979. Effective deme sizes during long-term evolution estimated from rates of chromosome rearrangements. Evolution, 33, 234-251.

LANGOR, D. W. AND SPERLING, F. A. H. 1997. Mitochondrial DNA sequence divergence in weevils of the Pissodes stobi species complex (Coleoptera: Curculionidae). Insect Mol. Biol., 6, 255-265.

LUNT, D. H., ZHANG, D.-X., SYMURA, J. M. AND HEWITT, G. M. 1996. The insect cytochrome oxidase I gene: evolutionary patterns and conserved primers for phylogenetic studies. Insect Mol. Biol., 5, 153-165.

MADDISON, W. P. AND MADDISON, D. R. 1992. MacClade, version 3. Sinauer Associates, Sunderland, MA.

MAYR, E. AND O'HARA, R. J. 1986. The biogeographic evidence supporting the Pleistocene forest refuge hypothesis. Evolution, 40, 55-67. 
MOLLER, H. 1985. Tree wetas (Hemideina crassicruris) (Orthoptera: Stenopelmatidae) of Stephens Island, Cook Strait. N. Z. J. Zool., 12, 55-69.

MORGAN-RICHARDS, M. 1997. Intraspecific karyotype variation is not concordant with allozyme variation in the Auckland tree weta of New Zealand, Hemideina thoracica (Orthoptera: Stenopelmatidae). Biol. J. Linn. Soc., 60, 423-442.

PHILLIPS, C. A. 1994. Geographic distribution of mitochondrial DNA variants and the historical biogeography of the spotted salamander, Ambystoma maculatum. Evolution, 48, 597-607.

RAYMOND, M. AND ROUSSET, F. 1995. GENEPOP, population genetics software for exact tests and ecumenicism. J. Hered., 86, 248-249.

SACCONe, C., De Giorgi, C., Gissi, C., Pesole, G. et AL. 1999. Evolutionary genomics in metazoa: the mitochondrial DNA as a model system. Gene, 238, 195-209.

SCHNEIDER, S., KUEFFER, J.-M., ROESSLI, D. AND EXCOFFIER, L. 1997. ARLEQUIN, version 1.1: software for population genetics data analysis. Genetic and Biometry Laboratory. University of Geneva, Switzerland.

SEARlE, J. B. 1993. Chromosomal hybrid zones in eutherian mammals. In: Harrison, R. G. (ed.) Hybrid Zones and the Evolutionary Process, pp. 140-164. Oxford University Press, New York.

SIMON, C., FRATI, F., BECKENBACH, A., CRESPI, B. J. ET AL. 1994. Evolution, weighting, and phylogenetic utility of mitochondrial gene sequences and a compilation of conserved polymerase chain reaction primers. Ann. Entomol. Soc. Am., 87, 651-701.

STAUFFER, C., LAKATOS, F. AND HEWITT, G. M. 1997. The phylogenetic relationships of seven European Ips (Scolytidae, Ipinae) species. Insect Mol. Biol., 6, 233-240.

Stevens, G. 1981. New Zealand adrift: the theory of continental drift in a New Zealand setting. Reed, Wellington.

SUNNUCKS, P. AND HALE, D. F. 1996. Numerous transposed sequences of mitochondrial cytochrome oxidase I-II in aphids of the genus Sitobion (Hemiptera: Aphididae). Mol. Biol. Evol., 13, 510-524.
SUNNUCKS, P., ENGLAND, P. R., TAYLOR, A. C. AND HALE, D. F. 1996. Microsatellite and chromosome evolution of parthenogenetic Sitobion aphids in Australia. Genetics, 144, 747-756.

SUNNUCKS, P., WILSON, A. C. C., BEHEREGARAY, L. B., ZENGER, K. $E T A L$. 2000. SSCP is not so difficult: the application and utility of single-stranded conformation polymorphism in evolutionary biology and molecular ecology. Mol. Ecol., 9, 1699-1710.

SWOFFORD, D. L. 1998. PAUP*. Phylogenetic Analysis Using Parsimony (* and other methods), version $4.01 \mathrm{~b}$. Sinauer Associates, Sunderland MA.

TABERlet, P., FUMAGAlli, L. AND HAUSSER, J. 1994. Chromosomal versus mitochondrial-DNA evolution - tracking the evolutionary history of the southwestern European populations of the Sorex araneus group (Mammalia, Insectivora). Evolution, 48, 623-636.

TREWICK, S. A. 2000. Mitochondrial sequences support allozyme evidence for cryptic radiation of New Zealand Peripatoides. Mol. Ecol., 9, 269-282.

TREWICK, S. A. AND MORGAN-RICHARDS, M. 1995. On the distribution of tree weta in the North Island, New Zealand. J. R. Soc. N. Z., 25, 1-9.

TREWICK, S. A., WALLIS, G. P. AND MORGAN-RICHARDS, M. 2000. Phylogeographic pattern correlates with Pliocene mountainbuilding in the alpine scree weta (Orthoptera, Anostostomatidae). Mol. Ecol., 9, 657-666.

WALlis, G. P. AND ARNTZEN, J. W. 1989. Mitochondrial-DNA variation in the crested newt superspecies: limited cytoplasmic gene flow among species. Evolution, 43, 88-104.

White, M. J. D. 1978. Modes of Speciation. W H Freeman, San Francisco.

WILSON, C. S. AND WALKer, G. P. L. 1985. The Taupo eruption, New Zealand. I. General aspects. Phil. Trans. R. Soc. A, 314, 199-228.

YANG, Z. 1994. Estimating the pattern of nucleotide substitution. J. Mol. Evol., 39, 105-111. 